\title{
Supplementation of Dietary Nano Zn-Phytogenic on Performance, Antioxidant Activity, and Population of Intestinal Pathogenic Bacteria in Broiler Chickens
}

\author{
C. Hidayat ${ }^{\mathrm{a}, \mathrm{c}, *}$, Sumiati ${ }^{\mathrm{b}}$, A. Jayanegara ${ }^{\mathrm{b}}$, \& E. Wina ${ }^{\mathrm{c}}$ \\ ${ }^{a}$ Graduate School of Nutrition and Feed Science, Faculty of Animal Science, IPB University \\ (Bogor Agricultural University) \\ ${ }^{b}$ Department of Nutrition and Feed Technology, Faculty of Animal Science, IPB University \\ (Bogor Agricultural University) \\ Kampus IPB Dramaga, Bogor 16680, Indonesia \\ Indonesian Research Institute for Animal Production, \\ Ciawi Bogor 16720, Indonesia \\ *Corresponding author: hidayat_c2p@yahoo.com \\ (Received 28-07-2020; Revised 14-09-2020; Accepted 09-10--2020)
}

\begin{abstract}
Zinc is one of the essential minerals that are important for poultry. The disadvantage of $\mathrm{Zn}$ in the conventional form is its low bioavailability. One of the efforts to increase the bioavailability of $\mathrm{Zn}$ is to make it in a nano form. Nano Zn-Phytogenic (NZP), is a combination of $\mathrm{Zn}$ and phytogenic compounds of plants in nanoparticle size. The NZP was self-produced utilizing the green synthesis process of inorganic $\mathrm{Zn}$ and guava leave extract (Psidium guajava). The objective of this study was to evaluate the effects of supplementation NZP in diet on the performance, antioxidant status, and population of pathogenic intestinal bacteria (Escherichia coli and Salmonella sp) of broilers chicken. This study used 180 males and 180 females of Lohman broilers day old chick (DOC). The experiment was subjected to a completely randomized design with 6 (six) treatments and 5 (five) replications, and each experimental unit consisted of 12 DOCs ( 6 males and 6 females). The treatment given in this study were; R1= basal diet; $\mathbf{R} 2=\mathbf{R} 1+\mathrm{Zn}$ Sulfate $(90 \mathrm{mg} \mathrm{Zn} / \mathrm{kg})+5.32 \mathrm{mg} / \mathrm{kg}$ guava leaf meal (added as a source of phytogenic compounds); R3= R1 + NZP (45 mg Zn/kg); R4= R1 + NZP (90 mg Zn/kg); R5= R1 + NZP (135 mg Zn/kg); $R 6=R 1+N Z P(180 \mathrm{mg} \mathrm{Zn/kg})$. The variables observed were performance, antioxidant activity in meat, and population of pathogenic intestinal bacteria ( $E$. coli and Salmonella sp) of broiler chicken. The results showed that the addition of NZP up to a dose of $90 \mathrm{mg} \mathrm{Zn/kg}$ in the diet improved $(\mathrm{p}<0.05)$ body weight gain compared to the basal diet. The addition of NZP had no significant effect on the FCR. The addition of NZP increased $(\mathrm{p}<0.05)$ SOD activity in meat when compared with the dietary treatment without NZP. Groups of chicken fed NZP $(\mathbf{R} 3, \mathbf{R} 4, \mathbf{R} 5, \mathbf{R} 6)$ had significantly $(\mathrm{p}<0.05)$ lower E. coli and Salmonella sp population. It could be concluded that the addition of NZP up to a dose of $90 \mathrm{mg} \mathrm{Zn} / \mathrm{kg}$ in the diet of broiler chicken had positive benefits in improving performance, increasing antioxidant activity, and reducing pathogenic intestinal bacteria (E. coli and Salmonella sp).
\end{abstract}

Keywords: Nano Zn-Phytogenic; broiler chicken; performance; antioxidant; intestinal pathogenic bacteria

\section{INTRODUCTION}

One of the essential minerals that are important for poultry is Zinc (Zn). It plays an important role in the metabolic process of protein and carbohydrates and in the process of growth and reproduction (Vinus \& Sheoran, 2017; Chand et al., 2014). Currently, the role of $\mathrm{Zn}$ is expanding as antioxidant, anti-heat stress, and antibacterial agents (Parashuramulu et al., 2015; Zhao et al., 2014). This new role of $\mathrm{Zn}$ would be beneficial in tropical countries such as Indonesia, which has a higher temperature than the ideal temperature for rearing broilers chicken. Especially at this time, the Indonesian government has implemented a ban on the use of antibiotic growth promoters (AGP) in animal feed.
High environmental temperature decreased the performance and immune response of broilers (Laudadio et al., 2012). Heat stress supports the formation of reactive oxygen species (ROS) in excess amounts (Chand et al., 2017). Accordingly, a balance between ROS production and the antioxidant system must be established (Saleh et al., 2017). Dietary zinc (Zn) supplementation was reported to have a positive effect on the performance of growing poultry under heat stress conditions (Saleh et al., 2018). This positive effect is because zinc is a fundamental element required for the structure and function of more than 300 enzymes related to metabolism (Salim et al., 2011). Souza et al. (2019) report that Zn Nanoparticles have superior antibacterial activity against Gram-positive and Gram-negative pathogenic 
bacteria. Xe et al. (2011) revealed that the possibilities of antibacterial mechanism of action of zinc oxide nanoparticles on membrane damage are caused by a direct or electrostatic interaction between $\mathrm{ZnO}$ and cell surfaces, cellular internalization of $\mathrm{ZnO}$ nanoparticles, and the production of active oxygen species such as $\mathrm{H}_{2} \mathrm{O}_{2}$ in cells due to metal oxides. The function of $\mathrm{Zn}$ nanoparticles as anti-bacteria is the same as the function of the antibiotic growth promoter (AGP) which suppress the growth of pathogenic bacteria.

It was reported, however, that the absorption of $\mathrm{Zn}$ in the digestive tract of broilers was very low (Swain et al., 2012). Recently, one of the efforts to improve the bioavailability of $\mathrm{Zn}$ is developing nanoparticle of $\mathrm{Zn}$ (Fathi et al., 2016a; Zhao et al., 2014). Zhao et al. (2014) reported that $\mathrm{Zn}$ in the form of nanoparticles had a stronger chemical activity than in a conventional form and played a role in oxidation reactions with various organic compounds. Nano minerals also had the ability to cross the small intestine and subsequently enter the blood, brain, lungs, heart, kidneys, spleen, liver, intestines, and stomach (Bergin \& Witzmann. 2013). Asheer et al. (2018) stated that $\mathrm{Zn}$ in nanoparticle size could improve growth, immunity, and reproduction and also acted as an antibacterial agent.

Nano Zn-Phytogenic (NZP) is a combination of Zn and phytogenic compounds of plants in nanoparticle size. The NZP was self-produced utilizing the green synthesis process of inorganic $\mathrm{Zn}$ and guava leaves extract (Psidium guajava), which acted as bioreductors and biostabilizers in the process of forming metal nanoparticles.

Guava leaves are reported to contain many active compounds, i.e., alkaloids, saponins, tannins, essential oils, flavonoids, and polyphenols (Pandey \& Shweta, 2011; Sinurat et al., 2018). Phytogenic compounds in guava leaf extract may have a function as feed additives, which will have positive benefits for the livestock body. Phytogenic compounds are potential to be used as an alternative growth promoter for broilers because they have the ability to improve gut health, performance, and immunity of broiler chicken without bacterial resistance (Murugesan et al., 2015). Many studies showed that phytogenic compounds had been shown to improve production performance and immune responses in broiler chickens (Dhama et al., 2015; Stanacev et al., 2011; Zhang et al., 2012; Zhou et al., 2013).

Nano Zn-Phytogenic (NZP) is a new feed additive product that has been synthesized using an environmentally friendly nanotechnology process (green synthesis), with the main content of $\mathrm{Zn}$ and phytogenic (phenolic) compounds from guava leaf extract. NZP is expected to have the ability to promote growth, antibacterial, and antioxidant in broiler chickens. NZP is a source of Zn nanoparticles, and phytogenic compounds are expected to have positive benefits on antioxidant activity in broiler chickens. The active component of plants, namely polyphenols, was reported to have a strong antioxidant capacity (Chrpová et al., 2010). Furthermore, Perry et al. (2010) state that $\mathrm{Zn}$ is a cofactor of a major antioxidant enzyme, namely
$\mathrm{Cu} / \mathrm{Zn}$ Superoxide Dismutase (SOD). In other studies, it has been reported that the addition of $\mathrm{Zn}$ oxide nanoparticles is successful in increasing the antioxidant capacity of broilers, as evidenced by the increased $\mathrm{Cu}$ / $\mathrm{Zn}$ SOD activity and the decreased accumulation of malondialdehyde (MDA) in serum and liver (Zhao et al., 2014). Therefore, the main objective of this study was to evaluate the effects of NZP addition into the diet on the performance, antioxidant status, and population of pathogenic intestinal bacteria (Escherichia coli and Salmonella sp) of broiler chickens.

\section{MATERIALS AND METHODS}

This study was approved by the ethical clearance of the treatment and use of experimental animals from the Animal Welfare Commission of the Agricultural Research and Development Agency with the ethical clearance number: Balitbangtan/Balitnak/A/01/2019.

This study used 360 sexed day old chick (DOC) broilers of Lohman strain. The chicks were vaccinated with ND IB, ND Killed, IB Transume vaccine. The average body weight of male DOC was $48.44 \mathrm{~g} / \mathrm{bird}$, while the female DOC was $48.11 \mathrm{~g} / \mathrm{bird}$.

The cage used was the open house cage with a litter system with rice husks. The cage was provided with half-covered curtains to allow enough airflow. There were 30 cages with the size of each cage was $1.5 \mathrm{~m} \times 1 \mathrm{~m}$. Every cage was equipped with a feeder trough, drinking water, and brooder heater. Dietary treatments were formulated based on Rostagno et al. (2017) (Table 1).

Nano Zn-Phytogenic (NZP) has been characterized physically and chemically (Hidayat et al., 2020) (in press). The phytogenic compounds in NZP were total phenol content from guava leaves. The process of making NZP was carried out by a green synthesis process in synthesizing metal nanoparticles. The main ingredients for making NZP were inorganic Zinc and guava leaf extract, forming complex bonds.

NZP treatment was added at doses equal to 0; 45; 90; 135; and $180 \mathrm{mg} \mathrm{Zn/kg}$. Rations were given in the mash form for the ages of 1-7 days old and in the crumble for the ages of 8-33 days old. The experimental design used was a complete design with 6 (six) treatments and 5 (five) replications. Each experimental unit consisted of 12 DOCs (6 males and 6 females). Feed and drinking water were given ad libitum. The treatments design are presented in Table 2.

\section{Management of Broiler Chicken}

Broiler chickens were confined in cages that had fluctuating temperatures between morning, afternoon, and evening, ranging from $26^{\circ} \mathrm{C}$ to $34^{\circ} \mathrm{C}$. The ambient temperature was recorded at $6 \mathrm{AM}, 12 \mathrm{PM}$; and 6 PM. The chickens were reared until the age of 33 days. The chickens weighing was carried out every week to determine body weight and to calculate body weight gain. The remaining feed provided was weighed once a week to calculate feed consumption. 
Table 1. Composition and nutrient contents of the basal diet for pre-starter, starter, and finisher periods

\begin{tabular}{|c|c|c|c|}
\hline Feedstuff & Prestarter (1-7 days old) & Starter (8-21 days old) & Finisher (22-33 days old) \\
\hline Corn $(\%)$ & 48.00 & 51.20 & 58.50 \\
\hline Soybean meal (\%) & 42.68 & 40 & 32.71 \\
\hline Palm oil (\%) & & & 4.60 \\
\hline Crude palm oil (\%) & 4.81 & 4.81 & \\
\hline $\mathrm{CaCO}_{3}(\%)$ & 1.94 & 1.72 & 1.92 \\
\hline $\mathrm{NaCl}(\%)$ & 0.47 & 0.45 & 0.4 \\
\hline DL-Methionine (\%) & 0.31 & 0.28 & 0.25 \\
\hline Lysine (\%) & 0.28 & 0.2 & 0.28 \\
\hline Tricalcium phosphate (\%) & 1.35 & 1.17 & 1.17 \\
\hline Premix ${ }^{a}(\%)$ & 0.17 & 0.17 & 0.17 \\
\hline Zinc sulfate (\%) & & & 0.001 \\
\hline Total & 100 & 100 & 100 \\
\hline \multicolumn{4}{|l|}{ Nutrient contents ${ }^{\mathrm{b}}$} \\
\hline Crude protein (\%) & 24.57 & 23.55 & 20.67 \\
\hline Metabolizable energy (kcal/kg) & 3018 & 3055 & 3155 \\
\hline Crude fat $(\%)$ & 6.82 & 6.93 & 6.96 \\
\hline Crude fiber (\%) & 2.48 & 2.48 & 2.44 \\
\hline Lysine $(\%)$ & 1.53 & 1.39 & 1.26 \\
\hline Methionine (\%) & 0.61 & 0.57 & 0.51 \\
\hline Methionine + Cysteine (\%) & 0.92 & 0.88 & 0.88 \\
\hline Calcium (\%) & 1.04 & 0.93 & 0.99 \\
\hline Available phosphorus (\%) & 0.47 & 0.43 & 0.42 \\
\hline $\mathrm{Na}(\%)$ & 0.23 & 0.22 & 0.20 \\
\hline $\mathrm{Cl}(\%)$ & 0.33 & 0.32 & 0.29 \\
\hline $\mathrm{Zn}(\mathrm{ppm})$ & 41.29 & 40.06 & 40.02 \\
\hline
\end{tabular}

Note: aProvides per kilogram of diet : vitamin A 15,000 IU; cholecalciferol, 3,900 IU; vitamin E 30 IU; vitamin K $3.0 \mathrm{mg}$; thiamine $2.4 \mathrm{mg}$; riboflavin, 9.0 $\mathrm{mg}$; vitamin B6, $4.5 \mathrm{mg}$; vitamin B12, $0.021 \mathrm{mg}$; calcium pantothenate, $30 \mathrm{mg}$; niacin, $45 \mathrm{mg}$; folic acid $1.2 \mathrm{mg}$; biotin, $0.18 \mathrm{mg}$; choline (as choline chloride), $700 \mathrm{mg}$; Cu, $8 \mathrm{mg}$; Mn, $100 \mathrm{mg}$; Fe, $80 \mathrm{mg}$; I, $0.35 \mathrm{mg}$; Se, $0.15 \mathrm{mg}$.

bObtained using the calculation method based on the nutrient content reported by the laboratory analysis of the Indonesian Research Institute for Animal Production, except for metabolic energy based on Rostagno et al. (2017).

Table 2. Nano Zn-Phytogenic (NZP) experimental diets

\begin{tabular}{|c|c|c|}
\hline Treatments & Description & Total $\mathrm{Zn}$ on $\operatorname{diet}(\mathrm{mg} / \mathrm{kg})$ \\
\hline R1 & Basal diet (Zn content according to NRC (1994); 40 mg/kg). & 40 \\
\hline R2 & $\begin{array}{l}\mathrm{R} 1+(90 \mathrm{mg} / \mathrm{kg} \text { Zinc Sulfate (conventional } \mathrm{Zn})+5.32 \mathrm{mg} / \mathrm{kg} \text { guava leaf flour (adding as a } \\
\text { source of phytogenic compounds)). Phenol content } 0.63 \mathrm{mg} / \mathrm{kg} \text {. }\end{array}$ & 130 \\
\hline R3 & R1 + NZP (45 mg Zn/kg), Phenol content $0.32 \mathrm{mg} / \mathrm{kg}$ & 85 \\
\hline R4 & R1 + NZP (90 mg Zn/kg), Phenol content 0.63 mg/kg & 130 \\
\hline R5 & R1 + NZP (135 mg Zn/kg), Phenol content $0.94 \mathrm{mg} / \mathrm{kg}$ & 180 \\
\hline R6 & R1 + NZP (180 mg Zn/kg), Phenol content $1.26 \mathrm{mg} / \mathrm{kg}$ & 220 \\
\hline
\end{tabular}

Note: The NZP used in the feeding trial contained $6.12 \% \mathrm{Zn}$ and $430 \mathrm{mg} / \mathrm{kg}$ of total phenol. Guava leaves used contained $11.85 \%$ of total phenol.

\section{Observation of Broiler Chicken Performance}

Feed consumption (g/bird) was measured based on the difference between the ration given and the remaining rations left in the feeder trough, divided by the number of chickens in one cage. Body weight (g/ bird) was measured by weighing the chickens in each cage each week, divided by the number of the chicken. Body-weight gain (g/bird) was calculated by subtracting the final total body weight by the total initial body weight and divided by the number of chickens. The feed conversion ratio was measured by dividing the average feed consumed by the average body-weight gain.

\section{Analysis of meat Superoxide Dismutase (SOD)}

Measurement of Superoxide Dismutase (SOD) enzyme activity in meat followed the procedure described by Martin Jr et al. (1987). The sample was prepared by weighing $1 \mathrm{~g}$ of fresh thigh meat, and put in a tube, added $2 \mathrm{~mL}$ of Phosphate Buffered Saline (PBS), homogenized and then centrifuged at 10000 rpm for 20 minutes. The supernatant was transferred into another tube as a sample for the next analysis. SOD levels were determined biochemically using the RanSOD ${ }^{\circledR}$ kit. Reagents in this kit consisted of a mixed substrate containing xanthine, phosphate buffer to 
dilute (both standard and sample), xanthine oxidase, and standard solution (CAL). The reagents were then used to make a standard curve. At first, $25 \mu \mathrm{L}$ of the sample was put into the cuvette, and $850 \mu \mathrm{L}$ of the mixed substrate was added and mixed well. To inhibit SOD, $5 \mathrm{~mL}$ of sodium cyanide was added to the mixture until it was well mixed. After that, $125 \mu \mathrm{L}$ of xanthine oxidase was added. The light absorption rate was read at a wavelength of $505 \mathrm{~nm}$ with a GENESYS $10 \mathrm{~S}$ UV-Vis Spectrophotometer-Printer IThermo Scientific ex. USA. Superoxide dismutase levels were determined using equations obtained from the standard curves.

\section{Measurement of Meat Malondialdehyde (MDA)}

Meat sample preparation was carried out by following the methods of Jung et al. (2016) with some modifications. Homogenate of chicken meat for MDA analysis was made by using $1 \mathrm{~g}$ of ground meat in cold conditions then added with $2 \mathrm{~mL}$ of PBS solution $(1.15 \mathrm{~g}$ $\mathrm{KCl}$ in $100 \mathrm{~mL} \mathrm{PBS}$ ) with a $\mathrm{pH}$ of 7.4 and homogenized. The resulting homogenate was centrifuged at $10000 \mathrm{rpm}$ for 20 minutes. The supernatant was taken and immediately stored at $-20^{\circ} \mathrm{C}$. The measurement of MDA level was then carried out by the method of thiobarbituric acid-reactive substance (TBARS). The procedure was initiated by preparing a standard stock solution of MDA in aquabidest with seven different concentrations (standard blank, $0.25-1.6 \mathrm{~mol}$ ). The $2 \mu \mathrm{L}$ sample was put into a centrifuge tube and added $1800 \mu \mathrm{L}$ of aquabidest, and $1000 \mu \mathrm{L}$ of $20 \%$ TCA, and $2000 \mu \mathrm{L}$ of TBA $0.67 \%$. Then the mixture was heated at $95^{\circ} \mathrm{C}$ for 10 minutes. The solution was allowed to reach room temperature, and then it was centrifuged at $3000 \mathrm{rpm}$ for 10 minutes. The procedure was also applied to the blank. The supernatant was carefully taken and then measured for its absorption with a GENESYS 10S UV-Vis SpectrophotometerPrinter/Thermo Scientific ex. USA at a wavelength of $530 \mathrm{~nm}$. MDA standard curves were made with a concentration of $0 \mathrm{nmol} ; 0.0125 \mathrm{nmol} ; 0.025 \mathrm{nmol} ; 0.05$ nmol; $0.1 \mathrm{nmol} ; 0.4 \mathrm{nmol} ; 1.6 \mathrm{nmol}$; and $32 \mathrm{nmol}$ in 2000 $\mu \mathrm{L}$. The sample MDA level was calculated by using the standard curve.

\section{Measurement of Escherichia coli and Salmonella sp Population in the Intestine}

Concentrations of E. coli and Salmonella in the intestinal digesta were measured by taking the sample of digesta from the ileum portion of the selected bird from each treatment replication. The digesta was removed from the ileum, then put in a sterile plastic, and placed in a cool box for the next laboratory analysis. Calculations of E. coli and Salmonella sp concentrations were carried out using a dilution method according to Balouiri et al. (2016); $1 \mathrm{~g}$ of sample was diluted with 9 $\mathrm{mL}$ of $\mathrm{KH}_{2} \mathrm{PO}_{4}$ solution. Dilution was carried out from $10^{-1}-10^{-4}$, then from each dilution, $1 \mathrm{~mL}$ of solution was pipetted and inserted into a petri dish that has been coded in duplicate. Furthermore, Eosin Methylene Blue Agar (EMBA) was poured, homogenized, and then incubated for $24-48$ hours with a temperature of $37^{\circ} \mathrm{C}$.

\section{Data Analysis}

Data were analyzed statistically using a variety of tests (ANOVA). Firstly, the data were tested for normality. The normal data were then analyzed with ANOVA, if there were significant $(\mathrm{p}<0.05)$ differences the analysis was continued for Duncan's test. The polynomial test was performed on body-weight gain data in order to determine the optimum dose of NZP. Some variables (meat antioxidant activity, populations of E. coli and Salmonella sp on intestinal (ileal) digesta) were tested by an orthogonal contrast to see the effect of with and without NZP addition treatment excluded treatment 2 (R2).

\section{RESULTS}

\section{Temperature and Humidity Conditions during Broiler Maintenance}

Observing the effect of NZP addition in broiler diet involves the recording of temperature and humidity of the air around the experimental cage, and the figures are presented in Table 3. The chickens were exposed to heat from the environment for \pm 12 hours at temperatures ranging from $25.2-31.5^{\circ} \mathrm{C}$ and humidity $49.52 \%-72.6 \%$.

\section{Addition of Nano Zn-Phytogenic (NZP) on the Performance of Broiler Chickens}

The average consumptions of $\mathrm{Zn}$ and phenol (mg/ bird) for the treatment groups are presented in Table 4. Meanwhile, the Scatterplot and regression lines of the effect of increasing dose $(\mathrm{mg} / \mathrm{kg}$ ) of NZP on body weight gain $(\mathrm{g} / \mathrm{bird})$ of the chickens are presented in Figure 1. The addition of NZP had a significant effect $(p<0.05)$ on feed consumption. The use of NZP up to a dose of $135 \mathrm{mg} / \mathrm{kg}$ did not influence feed consumption compared to R1 (without the addition of NZP) and R2 (addition of conventional $\mathrm{Zn}$ ). Feed consumption decreased when adding NZP at a dose of $180 \mathrm{mg} \mathrm{Zn/kg}$ (R6). Body weight gain (BWG) and body weight (BW) of the chickens were affected $(p<0.05)$ by the addition of NZP. BWG and BW for the treatment group, given the addition of NZP at doses of 45 and $90 \mathrm{mg} \mathrm{Zn/kg} \mathrm{did} \mathrm{not}$ differ significantly from the treatment group that was fed conventional $\mathrm{Zn}$ at a dose of $90 \mathrm{mg} \mathrm{Zn/kg}$ (R2). The addition of NZP at a dose of $180 \mathrm{mg} \mathrm{Zn/kg}$ decreased BWG and BW. The addition of NZP had no significant effect on the FCR. In this study, chickens in R3 treatment diet (45 mg Zn/kg dose from NZP) showed relatively similar FCR to chickens fed R2 treatment diet (90 mg $\mathrm{Zn} / \mathrm{kg}$ of conventional Zn).

\section{Addition of Nano Zn-Phytogenic (NZP) on Meat Antioxidant Activity}

The effect of adding NZP on the meat antioxidant activity (Superoxide Dismutase/SOD) and lipid oxidation product (Malondialdehyde/MDA) are presented in Table 5. The addition of NZP increased $(p<0.05)$ SOD activity when compared with the control group (R1) without the addition of NZP. This result was also shown 
Table 3. Temperature and relative humidity in the animal house during the course of the experiment of dietary Nano Zn-Phytogenic (NZP) in broiler chickens

\begin{tabular}{|c|c|c|c|c|c|c|c|c|}
\hline \multirow[b]{2}{*}{ Week } & \multicolumn{2}{|c|}{ Morning (6 AM) } & \multicolumn{2}{|c|}{ Noon (12 PM) } & \multicolumn{2}{|c|}{ Afternoon (6 PM) } & \multicolumn{2}{|c|}{ Recommended $^{1)}$} \\
\hline & $\begin{array}{c}\text { Temperature } \\
\left({ }^{\circ} \mathrm{C}\right)\end{array}$ & $\begin{array}{l}\text { Relative hu- } \\
\text { midity (\%) }\end{array}$ & $\begin{array}{c}\text { Temperature } \\
\left({ }^{\circ} \mathrm{C}\right)\end{array}$ & $\begin{array}{l}\text { Relative hu- } \\
\text { midity (\%) }\end{array}$ & $\begin{array}{c}\text { Temperature } \\
\left({ }^{\circ} \mathrm{C}\right)\end{array}$ & $\begin{array}{l}\text { Relative hu- } \\
\text { midity (\%) }\end{array}$ & $\begin{array}{c}\text { Temperature } \\
\left({ }^{\circ} \mathrm{C}\right)\end{array}$ & $\begin{array}{c}\text { Relative hu- } \\
\text { midity (\%) }\end{array}$ \\
\hline 1 & 26.94 & 61.00 & 34.97 & 45.57 & 33.51 & 41.57 & $27-30$ & $60-70$ \\
\hline 2 & 26.94 & 72.29 & 30.96 & 59.29 & 31.10 & 59.00 & $25-26$ & $60-70$ \\
\hline 3 & 22.07 & 73.43 & 29.86 & 49.43 & 30.37 & 48.29 & $22-24$ & $60-70$ \\
\hline 4 & 23.97 & 77.86 & 31.29 & 51.29 & 31.13 & 51.29 & $20-21$ & $60-70$ \\
\hline 5 & 20.03 & 64.66 & 26.24 & 41.59 & 26.75 & 40.37 & $20-21$ & $60-70$ \\
\hline Average & 25.00 & 72.06 & 31.70 & 50.94 & 31.50 & 49.52 & & \\
\hline SEM & 0.48 & 1.48 & 0.41 & 1.23 & 0.35 & 1.92 & & \\
\hline
\end{tabular}

Note: ${ }^{1}$ Lohman (2009)

Table 4. Performance of broiler chicken fed experimental Nano Zn-Phytogenic (NZP) diet up to the age of 33 days

\begin{tabular}{lcccccc}
\hline Treatment & \multicolumn{5}{c}{ Variables } \\
\cline { 2 - 6 } & $\begin{array}{c}\text { Feed consumption } \\
(\mathrm{g} / \mathrm{bird})\end{array}$ & $\begin{array}{c}\text { Body weight gain } \\
(\mathrm{g} / \mathrm{bird})\end{array}$ & $\begin{array}{c}\text { Body weight } \\
(\mathrm{g} / \mathrm{bird})\end{array}$ & FCR & $\begin{array}{c}\text { Zn consumption } \\
(\mathrm{mg} / \mathrm{bird})\end{array}$ & $\begin{array}{c}\text { Phenol consumption } \\
(\mathrm{mg} / \mathrm{bird})\end{array}$ \\
\hline R1 & $2,164.20^{\mathrm{a}}$ & $1,257 \mathrm{~b}^{\mathrm{c}}$ & $1,307^{\mathrm{ab}}$ & 1.67 & 86.57 & 0 \\
R2 & $2,291.40^{\mathrm{a}}$ & $1,384^{\mathrm{a}}$ & $1,432^{\mathrm{a}}$ & 1.58 & 297.89 & 1.45 \\
R3 & $2,076.80^{\mathrm{ab}}$ & $1,310^{\mathrm{ab}}$ & $1,357^{\mathrm{a}}$ & 1.58 & 176.53 & 0.66 \\
R4 & $2,235.70^{\mathrm{a}}$ & $1,352^{\mathrm{ab}}$ & $1,401^{\mathrm{a}}$ & 1.64 & 290.65 & 1.41 \\
R5 & $2,053.10^{\mathrm{ab}}$ & $1,259^{\mathrm{bc}}$ & $1,307^{\mathrm{ab}}$ & 1.56 & 359.29 & 1.95 \\
R6 & $1,851.30^{\mathrm{b}}$ & $1,176^{\mathrm{c}}$ & $1,224^{\mathrm{b}}$ & 1.57 & 407.29 & 2.34 \\
SEM & 44.30 & 19.43 & 20.17 & 0.017 & & \\
p-value & 0.0452 & 0.0116 & 0.0118 & 0.412 & & \\
\hline
\end{tabular}

Note: R1= basal diet; R2= R1 + Zn Sulfate $(90 \mathrm{mg} \mathrm{Zn/kg)} \mathrm{+} 5.32 \mathrm{mg} / \mathrm{kg}$ guava leaf flour; R3= R1 + NZF (45 mg Zn/kg); R4= R1 + NZF (90 mg Zn/kg); R5= $\mathrm{R} 1+\mathrm{NZF}(135 \mathrm{mg} \mathrm{Zn/kg)} ; \mathrm{R} 6=\mathrm{R} 1+\mathrm{NZF}(180 \mathrm{mg} \mathrm{Zn/kg})$. Means in the same column with different supperscripts differ significantly (p<0.05).

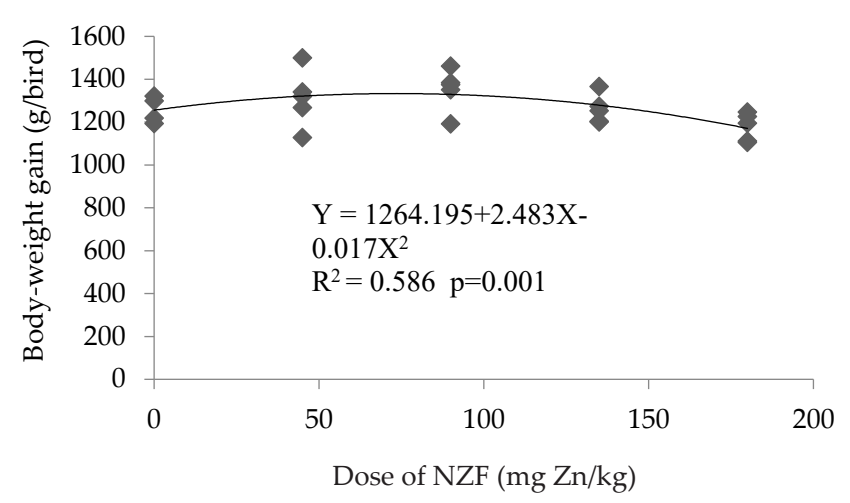

Figure 1. Scatter plot and regression line of body weight gain of broiler chickens fed experimental Nano ZnPhytogenic (NZP) diet

by the significant $(p<0.05)$ effect of the orthogonal contrast test (Table 5) between groups without the addition of the NZP treatment (R1) and groups with the addition of NZP (R3, R4, R5, R6). The addition of NZP in the diet significantly $(\mathrm{p}<0.1)$ reduced lipid oxidation (Malondialdehyde/MDA) in meat as were shown by the results of the orthogonal contrast analysis between the control group without the addition of NZF (R1) and groups with the addition of NZP (R3, R4, R5, R6).

\section{Population of Escherichia coli and Salmonella sp in the Intestine}

The effects of dietary NZP on the populations of E. coli and Salmonella sp in the intestinal digesta (ileum) are presented in Table 6. The addition of NZP significantly $(p<0.05)$ decreased the number of $E$. coli compared to the control group without the addition of NZP (R1). The addition of NZP at a dose of $90 \mathrm{mg}$ $\mathrm{Zn} / \mathrm{kg}$ resulted in the lowest number of $E$. coli bacteria compared to other treatments. The addition of NZP was also able to reduce the number of Salmonella $s p$ bacteria in the intestine compared to the control group without the addition of NZP (R1) and the treatment group that was given the addition of conventional $\mathrm{Zn}$ at a dose of $90 \mathrm{mg} \mathrm{Zn/kg}$ (R2). The orthogonal contrast test showed that chickens in groups R3, R4, R5, and R6 significantly $(\mathrm{p}<0.01)$ decreased Salmonella $s p$ population compared to the control group without the addition of NZP (R1). The addition of NZP at a dose of $90 \mathrm{mg} \mathrm{Zn/kg}$ resulted in the lowest amount of Salmonella $s p$ bacteria compared to other treatments.

\section{DISCUSSION}

\section{Broiler Chickens Performance}

The addition of NZP at a dose of $180 \mathrm{mg} / \mathrm{kg}$ reduced feed palatability. This effect was thought to be re- 
Table 5. Antioxidant activity (Superoxide Dismutase/SOD) and lipid oxidation products (Malondialdehyde/MDA) in thigh meat of broilers chickens fed experimental Nano Zn-Phytogenic (NZP) diet up to the age of 33 days

\begin{tabular}{lcc}
\hline \multirow{2}{*}{ Treatments } & \multicolumn{2}{c}{ Variables } \\
\cline { 2 - 3 } & SOD $(\mathrm{U} / \mathrm{mL})$ & MDA $(\mathrm{nmol} / \mathrm{mL})$ \\
\hline R1 & $14.5^{\mathrm{c}}$ & $0.46^{\mathrm{a}}$ \\
R2 & $21.9^{\mathrm{ab}}$ & $0.13^{\mathrm{b}}$ \\
R3 & $22.8^{\mathrm{ab}}$ & $0.15^{\mathrm{b}}$ \\
R4 & $19.6^{\mathrm{bc}}$ & $0.16^{\mathrm{b}}$ \\
R5 & $21.1^{\mathrm{ab}}$ & $0.13^{\mathrm{b}}$ \\
R6 & $26.5^{\mathrm{a}}$ & $0.19^{\mathrm{ab}}$ \\
SEM & 1.05 & 0.039 \\
p-value & 0.031 & 0.104 \\
Contrast orthogonal p-value: & \\
R1 vs R3, R4, R5, R6 & 0.010 & 0.059 \\
\hline
\end{tabular}

Note: R1= basal diet; $\mathrm{R} 2=\mathrm{R} 1+\mathrm{Zn}$ Sulfate $(90 \mathrm{mg} \mathrm{Zn} / \mathrm{kg})+5.32 \mathrm{mg} / \mathrm{kg}$ guava leaf flour; R3= R1 + NZF (45 mg Zn/kg); R4= R1 + NZF (90 $\mathrm{mg} Z \mathrm{nn} / \mathrm{kg}) ; \mathrm{R} 5=\mathrm{R} 1+\mathrm{NZF}(135 \mathrm{mg} \mathrm{Zn} / \mathrm{kg}) ; \mathrm{R} 6=\mathrm{R} 1+\mathrm{NZF}(180 \mathrm{mg}$ $\mathrm{Zn} / \mathrm{kg}$ ). Means in the same column with different supperscripts differ significantly $(\mathrm{p}<0.05)$.

lated to the cumulative consumption of $\mathrm{Zn}$ and phenols that enter the body of broilers chickens. Table 4 showed the consumption of $\mathrm{Zn}$ and phenol (mg/bird) of the experimental chickens for each treatment group during the observation period. The chickens in the R6 treatment consumed a total of $407.29 \mathrm{mg}$ of $\mathrm{Zn} / \mathrm{bird}$ and consumed a phenol of $2.34 \mathrm{mg} / \mathrm{bird}$. Ahmadi et al. (2013) reported that feed consumption decreased significantly with the addition of nano $\mathrm{ZnO}$ in the diet of broiler chicken at doses of 60 and $90 \mathrm{mg} / \mathrm{kg}$. Mahmoud et al. (2013) reported that the addition of $1 \%$ guava leaves in the diet of broiler chicken reduced feed consumption. Meanwhile, Starcevic et al. (2015) reported that phenol compounds in the form of tannins exhibited anti-nutritional and toxic effects that would depend on their intake and bioavailability. The results of the study indicated that the cumulative consumption of $\mathrm{Zn}$ and phenol compounds in high doses was one of the factors in decreasing feed consumption in broiler chickens. In the present study, feed consumption ranged from 1851-2291 g/bird, which was lower than the normal feed consumption of broiler chickens as suggested by Lohman (2009) (more than $2611 \mathrm{~g} /$ bird).

The ambient temperature around the cage reached $33^{\circ} \mathrm{C}$ during the day, and this high environmental temperature was the main factor that probably caused the low feed consumption. High air temperatures were reported to reduce feed consumption of broiler chickens (Syafwani et al., 2011). The reduced feed consumption was due to the adjustment of body's temperature of the chicken to the environment temperature by suppressing endogenous heat production through the reduction of feed consumption. Syafwani et al. (2011) also stated that in order to increase survival rates under high ambient temperatures, broilers chicken reduced feed consumption in order to reduce metabolic heat production, which eventually would reduce body weight.
Table 6. Populations of Eschericia coli and Salmonella sp on intestinal (ileal) digesta of broiler chickens fed experimental Nano Zn-Phytogenic (NZP) diet up to the age of 33 days

\begin{tabular}{lcc}
\hline \multirow{2}{*}{ Treatments } & \multicolumn{2}{c}{ Population } \\
\cline { 2 - 3 } & $\begin{array}{c}\text { Escherichia coli } \\
(\log \text { CFU/g) }\end{array}$ & $\begin{array}{c}\text { Salmonella sp } \\
(\text { log CFU/g) }\end{array}$ \\
\hline R1 & $4.23^{\mathrm{A}}$ & $2.39^{\mathrm{A}}$ \\
R2 & $2.91^{\mathrm{AB}}$ & $1.89^{\mathrm{B}}$ \\
R3 & $3.56^{\mathrm{A}}$ & $1.13^{\mathrm{C}}$ \\
R4 & $1.00^{\mathrm{C}}$ & $1.00^{\mathrm{C}}$ \\
R5 & $1.47^{\mathrm{BC}}$ & $1.09^{\mathrm{C}}$ \\
R6 & $3.28^{\mathrm{A}}$ & $1.19^{\mathrm{C}}$ \\
SEM & 0.30 & 0.12 \\
p-value & 0.0023 & $<0.0001$ \\
Contrast orthogonal p-value: & \\
R1 vs R3, R4, R5, R6 & 0.004 & $<0.0001$ \\
\hline
\end{tabular}

Note: R1= basal diet; R2= R1 + Zn Sulfate $(90 \mathrm{mg} \mathrm{Zn/kg)}+5.32 \mathrm{mg} / \mathrm{kg}$ guava leaf flour; R3= R1 + NZF (45 mg Zn/kg); R4= R1 + NZF (90 $\mathrm{mg} \mathrm{Zn/kg);} \mathrm{R5=} \mathrm{R1} \mathrm{+} \mathrm{NZF} \mathrm{(135} \mathrm{mg} \mathrm{Zn/kg);} \mathrm{R6=} \mathrm{R1} \mathrm{+} \mathrm{NZF} \mathrm{(180} \mathrm{mg}$ $\mathrm{Zn} / \mathrm{kg}$ ). Means in the same column with different supperscripts differ significantly $(\mathrm{p}<0.01)$.

Achievement of body weight (BW) at 33 days (Table 4) of NZP treatment at a dose of $45 \mathrm{mg} \mathrm{Zn/kg} \mathrm{(R3)}$ was similar to the body weight of the group of broiler chickens fed ration supplemented with conventional $\mathrm{Zn}$ at a dose of $90 \mathrm{mg} \mathrm{Zn/kg}$ (R2). This result indicated an equal level of $\mathrm{Zn}$ efficiency when given in the form of NZP. The relationship between NZP doses and the body weight gain (BWG) was expressed in a regression formula of $Y=1264.195+2.483 X-0.017 X 2$ (Figure 1), showing that the optimum dose of dietary NZP producing the highest BWG was $73 \mathrm{mg} \mathrm{Zn/kg}$. The optimum dose of NZP addition was actually lower than the results obtained from a meta-analysis study, which was $90 \mathrm{mg}$ of non-nano particles $\mathrm{Zn} / \mathrm{kg}$ to reach the highest BWG (Hidayat et al., 2020).

These results indicated that the size of $\mathrm{Zn}$ particle changing to nanoparticle as in NZP products reduced the dose of $\mathrm{Zn}$ use in the feed, which might impact on increasing $\mathrm{Zn}$ bioavailability. Some reports indicated that the addition of $\mathrm{Zn}$ nanoparticles in the ration of broiler chickens had a positive effect on the increasing body weight of broiler chickens. Zhao et al. (2014) reported that the addition of 20 and $60 \mathrm{mg}$ nano- $\mathrm{Zn} /$ $\mathrm{kg}$ ration in broiler chickens increased body weight. Fathi et al. (2016b) also reported that the addition of nano $\mathrm{Zn}$ in the form of $\mathrm{ZnO}$ at a dose of $20 \mathrm{mg} / \mathrm{kg}$ significantly increased body weights of broiler chickens. This result showed that reducing the size of $\mathrm{Zn}$ particle had a positive effect on the growth of broiler chickens. Mohammadi et al. (2015) stated that the application of nanotechnology helped to provide $\mathrm{Zn}$ more efficiently. Particles in nanosize could by-pass conventional physiological pathways from the distribution and transportation of nutrients across tissues and cell membranes and protected $\mathrm{Zn}$ from the destruction process before reaching the target (Asheer et al., 2018). 
In this study, the addition of NZP at doses of 45 and $90 \mathrm{mg} \mathrm{Zn/kg}$ ratio had a positive effect on body weight gain. The positive effects of NZP addition, not only as an effect of $\mathrm{Zn}$ but also the effects of phytogenic compounds bound in NZP. Previously, several researchers (Stanacev et al., 2011; Dhama et al., 2015) reported that the use of phytogenic feed additives in the diet improved the performance of poultry. Mahmoud et al. (2013) also reported that phytogenic compounds obtained from guava leaves increased body weight gain of broiler chickens. Phytogenic feed additive improved the growth of broiler chickens due to the increase in the utilization of nutrients, stimulation of digestive enzymes (i.e., lipase, amylase, or protease), and improved microbiota ecosystem by controlling pathogenic bacteria in the digestive tract (Hashemi \& Davoodi, 2011).

However, on the contrary to the positive effects, the addition of NZP up to $180 \mathrm{mg} \mathrm{Zn} / \mathrm{kg}$ ration decreased BWG. Zhao et al. (2014) reported that Zn nanoparticles had a toxic effect if used in a high dose. Siddiqi et al. (2018) stated that $\mathrm{Zn}$ in the form of nanoparticles was much more active and could be quickly converted into ions in the stomach. This condition will cause the production of large amounts of metal ions and then be brought into the liver and kidneys for metabolism and excretion, which eventually caused damage of the liver and kidney tissues (Zhao et al., 2014). In addition, Zn in the form of nanoparticles was able to increase the biocompatibility of $\mathrm{Zn}$ against cells (Wahab et al., 2016). Some researchers (Lu et al., 2013; Boverhof et al., 2015) expressed concern about the possible negative effects of the use of nanoparticle material. Recently, acute toxicity of the use of nano- $\mathrm{ZnO}$ had been investigated either in vitro or in vivo (Sharma et al., 2012; Esmaeillou et al., 2013; Setyawati et al., 2015). The toxicity of nano-ZnO increased with a decrease in size as well as an increase in concentration (Yan et al., 2012; Lopes et al., 2014). Body weight and organ weight are general and sensitive indicators for identifying the harmful effects of drugs on animals (Nirogi et al., 2014). Jeevanandam et al. (2018) explained that nano minerals, despite being important supplying micro minerals, were actually toxic at a higher rate than the required dosage.

FCR of chickens fed diet supplemented with NZP were lower than those fed ration without NZP (R1). This result indicates that the addition of NZP has a positive benefit in increasing the efficiency of feed utilization. Some references reported that the addition of Zn nanoparticles provided a positive response to FCR. Ahmadi et al. (2013) stated that FCR was improved significantly through the addition of $\mathrm{ZnO}$ nanoparticles at doses of 60 and $90 \mathrm{mg} / \mathrm{kg}$. Similarly, Zhao et al. (2014) reported that the addition of $\mathrm{ZnO}$ nanoparticles to the basal diet produced better FCR at doses of 20 and 60 $\mathrm{mg} / \mathrm{kg}$. Meanwhile, Fathi et al. (2016a) found better feed efficiency in the addition of nano $\mathrm{ZnO}$ at a dose of 20 $\mathrm{mg} / \mathrm{kg}$ in the basal diet.

\section{Antioxidant Activity}

The antioxidant activity of SOD caused by dietary NZP at a dose of $45 \mathrm{mg} \mathrm{Zn/kg} \mathrm{(R3)} \mathrm{was} \mathrm{not} \mathrm{statistically}$ different from that caused by a diet with conventional $\mathrm{Zn}$ at a dose of $90 \mathrm{mg} \mathrm{Zn/kg}$. Zn is actually a cofactor for SOD and has an important function in antioxidant systems, such as an inhibitor of the oxidation process by protecting proteins and enzymes and as an inhibitor of free radical formation (Yuan et al., 2011). SOD is widely distributed and protects various organs and tissues from peroxidation (Fukai \& Fukai, 2011). The important role of $\mathrm{Zn}$ in immune response activities is related to the influence of $\mathrm{Zn}$ on the antioxidant defense mechanisms in the body (Lee, 2018). Marreiro et al. (2017) stated that Zn increased antioxidant activity by reducing the production of free radicals because Zn competes with the other minerals, such as copper and iron, in binding to the cell membranes.

The addition of NZP to the feed had a tendency to be able to inhibit lipid peroxidation. MDA is a product of the lipid oxidation process. A high MDA value indicated a high oxidized lipid value. Lipid oxidation is related to the level of antioxidant activity. Zn plays an important role in antioxidant activity, having an impact on reducing the lipid oxidation process (Hidayat et al., 2020). Lee (2018) explained that as a cofactor of many anti-oxidative enzymes, $\mathrm{Zn}$ plays a key role in reducing the production of free radicals. Previously, several researchers (Marreiro et al., 2017; Lee, 2018) reported that $\mathrm{Zn}$ was able to reduce MDA, which showed that $\mathrm{Zn}$ functioned as an antioxidant agent, reducing lipid peroxidation in the cell membranes. The positive effects of the addition of NZP are the increased antioxidant activity of SOD enzymes and having the ability to inhibit the occurrence of lipid peroxidation (MDA) in broiler chickens. Besides showing a positive benefit due to $\mathrm{Zn}$ content, NZP also has a positive effect due to its phytogenic elements contents. Lee et al. (2016) stated that plant phytogenic elements (phenols) had an antioxidant capacity. Meanwhile, Chrpová et al. (2010) suggested that the active component of plants, namely polyphenols, also had a strong antioxidant capacity. Hydrolyzed tannins, as part of polyphenols, are also reported to play a role as a powerful source of antioxidants (Mojzer et al., 2016). Moreover, guava leaves that were used in the NZP synthesis process had the potential as a source of antioxidants (Lee et al., 2012; Rivai et al., 2010). Bintarti (2014) also reported that guava leaf extract had antioxidant activity in a strong category.

\section{Populations of Escherichia coli and Salmonella sp Bacteria in the Intestine}

Nanoparticles were reported to have strong abilities in bacteriostatic (inhibiting the growth) and bactericides (killing the bacteria) (Arabi et al., 2012). E. coli and Salmonella $\mathrm{sp}$ are pathogenic bacteria that can be found in the intestines of animals (Iovine et al., 2015). Kemmett et al. (2014) stated that E. coli is the main factor in the mortality of the newly hatched chicks, which contributes to economic losses in the poultry industry. The addition of NZP at a dose of $90 \mathrm{mg} \mathrm{Zn} / \mathrm{kg}$ resulted in the lowest number of $E$. coli bacteria compared to the other treatment groups. The results of the orthogonal contrast test between the treatment group without NZP (R1) 
and with NZF (R3, R4, R5, R6), showed that there were significant differences $(\mathrm{p}<0.05)$ in the E. coli population in the intestine. The significant $(p<0.01)$ reduction in the number of Salmonella sp bacteria in the intestine was shown in chickens fed a diet containing NZP compared to the group fed control diet without NZP (R1) or the chickens that were fed a diet contained a conventional $\mathrm{Zn}$ at a dose of $90 \mathrm{mg} \mathrm{Zn/kg}$ ration. This condition was also confirmed by the orthogonal contrast test results, comparing the variable in the group of the chicken fed diet without NZP (R1) with the group of chickens fed the diet with NZP (R3, R4, R5, R6). The addition of NZP at a dose of $90 \mathrm{mg} \mathrm{Zn/kg}$ showed the lowest number of Salmonella sp bacteria compared to the other treatment groups. This result indicated that NZP had the potential to be developed as an antibacterial agent in broiler chicken's diet.

Seil \& Webster (2012) explained that nanoparticles had a greater surface area available to interact with the surface of bacteria to enhance the bactericidal effect as compared to large particles. Slavin et al. (2017) reported that nanomaterials released ions reacted with thiol groups (-SH) from proteins present on the cell surface. The protein protrudes through the cell wall, facilitate and allow the transportation of nutrients. Zn nanoparticles deactivate proteins, reduce membrane permeability, and ultimately cause cell death (Rajendran et al., 2010). Furthermore, Lahir (2020) added that minerals in the form of nano also was slowing the attachment of bacteria and inhibiting the formation of biofilms. The specific mode of action of nanoparticles against bacteria made it an ideal candidate as an antimicrobial agent without the risk of developing bacterial resistance (Arabi et al., 2012). The antibacterial activity shown by NZP was also caused by the activity of phytogenic compounds derived from guava leaf extracts incorporated in the NZP. The results of many studies indicated that phytogenic elements contained in guava leaves (flavonoids, gallocatechin) had the ability as an antibacterial, including against E. coli and Salmonella sp (Biswas et al., 2013). Phytogenic character of guava leaves (Psidium guajava L) was reported by Biswas et al. (2013) as a part of a plant containing antimicrobial compounds, i.e., tannins, essential oils (eugenol), fatty oils, resins, triterpenoids, flavonoids, and malic acid. Antimicrobial compounds in guava leaves had the ability to suppress Gram-positive and Gram-negative bacteria (Biswas et al., 2013).

\section{CONCLUSION}

Supplementation of Nano Zn-Phytogenic (NZP) up to a dose of $90 \mathrm{mg} \mathrm{Zn/kg}$ in the broiler chicken diet had positive benefits in improving performance, increasing antioxidant activity, and functioning as an antibacterial against pathogenic bacteria (Escherichia coli and Salmonella sp) in the intestine.

\section{CONFLICT OF INTEREST}

Anuraga Jayanegara and Elizabeth Wina serve as editors of the Tropical Animal Science Journal, but have no role in the decision to publish this article. The
Authors also certify that there is no conflict of interest with any financial, personal, or other relationships with other people or organization related to the material discussed in the manuscript.

\section{ACKNOWLEDGEMENT}

This work is part of the research funded by Indonesian Agency for Agricultural Research and Development through DIPA BALITBANGTAN.

\section{REFERENCES}

Ahmadi, F., Y. Ebrahimnezhad, N. M. Sis, \& J. Ghiasi. 2013. The effects of zinc oxide nanoparticles on performance, digestive organs and serum lipid concentrations in broiler chickens during starter period. Int. J. Biosci. 3:23-9. https:// doi.org/10.12692/ijb/3.7.23-29

Arabi, F., M. Imandar, M. Negahdary, M. Imandar, M.T. Noughabi, \& H. Akbari-Dastjerdi. 2012. Investigation antibacterial effect of zinc oxide nanoparticles upon life of Listeria monocytogenes. Ann. Biol. Res. 3:3679-3685.

Asheer, M., S. J. Manwar, M. A. Gole, S. Sirsat, M.R. Wade, K. K. Khose, \& S. S. Ali. 2018. Effect of dietary nano zinc oxide supplementation on performance and zinc bioavailability in broilers. Indian. J. Poult. Sci. 53: 70-75. https://doi. org/10.5958/0974-8180.2018.00004.1

Balouiri, M., M. Sadiki, \& S. A. Ibnsouda. 2016. Methods for in vitro evaluating antimicrobial activity: A review. J. Pharm. Anal. 6:71-79. https://doi.org/10.1016/j.jpha.2015.11.005

Bergin, I. L., \& F. A. Witzmann. 2013. Nanoparticle toxicity by the gastrointestinal route: evidence and knowledge gaps. Int. J. Biomed. Nanosci. Nanotechnol. 3: 1-2. https://doi. org/10.1504/IJBNN.2013.054515

Bintarti, T. 2014. Skrining fitokimia dan uji kemampuan sebagai antioksidan dari daun jambu biji (Psidium guajava. L). Jurnal Ilmiah PANNMED. 9: 40-44.

Biswas, B., K. Rogers, F. McLaughlin, D. Daniels, \& A. Yadav. 2013. Antimicrobial activities of leaf extract of guava (Psidium guajava L) on two gram-negatif and gram-positiv bacteria. Int. J. Microbiol. 2013:1-7. Article ID 746165. https://doi.org/10.1155/2013/746165

Boverhof, D.R., C.M. Bramante, J.H. Butala, S.F. Clancy, M. Lafranconi, \& J. West. 2015. Comparative assessment of nanomaterial definitions and safety evaluation considerations. Regul. Toxicol. Pharmacol. 73:137-150. https://doi. org/10.1016/j.yrtph.2015.06.001

Chand, N., S. Naz, A. Khan, S. Khan, \& R.U. Khan. 2014. Performance traits and immune response of broiler chicks treated with zinc and ascorbic acid supplementation during cyclic heat stress. Int. J. Biometeorol. 58:2153-2157. https://doi.org/10.1007/s00484-014-0815-7

Chand, N., S. Naz, H. Maris, R.U. Khan, S. Khan, \& M.S. Qureshi. 2017. Effect of betaine supplementation on the performance and immune response of heat stressed broilers. Pakistan. J. Zool. 49:1857-1862. https:/doi. org/10.17582/journal.pjz/2017.49.5.1857.1862

Chrpová, D., L. Kourimská, M.H. Gordon, V. Heřmanová, I. Roubičková, \& J. Panek. 2010. Antioxidant activity of selected phenols and herbs used in diets for medical conditions. Czech. J. Food. Sci. 28:317-325. https://doi. org $/ 10.17221 / 129 / 2010-C J F S$

Dhama, K., S.K. Latheef, S. Manis, H.A. Samad, K. Kartik, R. Tiwari, R.U. Khan, M. Al-Agawany, M.R. Farag, G.M. Alam, V. Laudadio, \& V. Tu Farelli. 2015. Multiple beneficial applications and modes of action of herbs in poultry health and production - A review. Int. J. Pharmacol. 
11:152-176. https://doi.org/10.3923/ijp.2015.152.176

Esmaeillou, M., M. Moharamnejad, R. Hsankhani, A.A. Tehrani, \& H. Maadi. 2013. Toxicity of $\mathrm{ZnO}$ nanoparticles in healthy adult mice. Environ. Toxicol. Pharmacol. 35: 6771. https://doi.org/10.1016/j.etap.2012.11.003

Fathi, M., M. Hydari, \& T. Tanha. 2016a. Effect of zinc oxide nanoparticles on antioxidant status, serum enzyme activities, biochemical parameters and performance in broiler chicken. J. Livest. 4:7-13.

Fathi, M. 2016b. Effects of zinc oxide nanoparticles supplementation on mortality due to ascites and performance growth in broiler chickens. Iran J. Appl. Anim. Sci. 6:389-394.

Fukai, T. \& M. U. Fukai. 2011. Superoxide dismutases: Role in redox signaling, vascular function, and diseases. Antioxid. Redox. Signal. 15: 1583-1606. https://doi.org/10.1089/ ars.2011.3999

Hashemi, S.R. \& H. Davoodi. 2011. Herbal plants and their derivatives as growth and health promoters in animal nutrition. Vet. Res. Commun. 35:169-180. https://doi. org/10.1007/s11259-010-9458-2

Hidayat, C., Sumiati, A. Jayanegara, \& E. Wina. 2020. Effect of zinc on the immune response and production performance of broilers: a meta-analysis. Asian-Australas. J. Anim. Sci. 33:465-479. https://doi.org/10.5713/ajas.19.0146

Iovine, R.O., C. Dejuste, F. Miranda, C. Filoni, M. G. Bueno, \& V. M. Carvalho. 2015. Isolation of Escherichia coli and Salmonella spp. from free-ranging wild animals. Brazilian. J. Microb. 46:1257-1263. https://doi.org/10.1590/ S1517-838246420140843

Jeevanandam, J., A. Barhoum, Y.S. Chan, A. Dufresne, \& M. K. Danquah. 2018. Review on nanoparticles and nanostructured materials: history, sources, toxicity and regulations. Beilstein. J. Nanotechnol. 9: 1050-1074. https://doi. org/10.3762/bjnano.9.98

Jung, S., K. C. Nam, \& C. Jo. 2016. Detection of malondialdehyde in processed meat products without interference from the ingredients. Food Chem. 209:90-94. https://doi. org/10.1016/j.foodchem.2016.04.035

Kemmett, K., N. J. Williams, G. Chaloner, S. Humphrey, P. Wigley, \& T. Humphrey. 2014. The contribution of systemic Escherichia coli infection to the early mortalities of commercial broiler chickens. Avian Pathol. 43:1: 37-42. https://doi.org/10.1080/03079457.2013.866213

Lahir, Y. K. 2020. Interactions at interface between nanomaterial's and biofilm: A general survey. Adv. Clin. Toxicol. 5:000192.

Laudadio, V., A. Dambrosio, G. Normanno, R.U. Khan, S. Naz, E. Rowghani, \& V. Tufarelli. 2012. Effect of reducing dietary protein level on performance responses and some microbiological aspects of broiler chickens under summer environmental conditions. Avian. Biology. Res. 5:88-92. https://doi.org/10.3184/175815512X13350180713553

Lee, M.T., W.C. Lin, B. Yu, \& T.T. Lee. 2016. Antioxidant capacity of phytochemicals and their potential effects on oxidative status in animals - A review. Asian-Australas. J. Anim. Sci. 30:299-308. https://doi.org/10.5713/ajas.16.0438

Lee, S.R. 2018. Critical role of zinc as either an antioxidant or a prooxidant in cellular systems. Oxid. Med. Cell. Longev. 2018:1-11. https://www.hindawi.com/journals/omcl/2018/9156285/. [15 August 2020]. https://doi. org/10.1155/2018/9156285

Lee, W.C., R. Mahmud, S. Pillai, S. Perumal, \& S. Ismail. 2012. Antioxidant activities of essential oil of Psidium guajava L. Leaves. APCBEE Procedia. 2: 86 - 91. https://doi. org/10.1016/j.apcbee.2012.06.016

Lohman. 2009. Lohman Broiler Management Manual. http:// www.incubatricipadovan.it/allegati/LOHMANN\%202. pdf. [1 Juli 2020].

Lopes, S., F. Ribeiro, J. Wojnarowicz, \& O. Witold. 2014. Zinc oxide nanoparticles toxicity to Daphnia magna: size-dependent effects and dissolution. Environ. Toxicol. Chem. 33: 190-198. https://doi.org/10.1002/etc.2413

Lu, X., Y. Liu, X. Kong, P.E. Lobie, C. Chen, \& T. Zhu. 2013. Nanotoxicity: a growing need for study in the endocrine system. Small. 9:1654-1671. https://doi.org/10.1002/ smll.201201517

Mahmoud, R.E., I. Doaa, \& M.E. Badawi. 2013. Effect of supplementation of broiler diets with guava leaves and/or olive oil on growth, meat composition, blood metabolites and immune response. Benha. Vet. Med J. 25: 23-32.

Marreiro, D. N., K. J. C. Cruz, J. B. S. Morais, J.B. Beserra, J. S. Severo, \& A. R. S. de Oliveira. 2017. Zinc and oxidative stress: Current mechanisms. Antioxidants. $6: 24$. https:// doi.org/10.3390/antiox6020024

Martin Jr, J.P., M. Dailey, \& E. Sugarman. 1987. Negative and positive assays of superoxide dismutase based on haematoxylin auto-oxidation. Arch. Biochem. Biophys. 255:329336. https://doi.org/10.1016/0003-9861(87)90400-0

Mohammadi, V., S. Ghazanfari, A. MohammadiSangcheshmeh, \& M.H. An Nazaran. 2015. Comparative effects of zinc-nano complexes, zinc-sulphate and zinc-methionine on performance in broiler chickens. Br. Poult. Sci. 56:486-493. https://doi.org/10.1080/00071668.2015.1064093

Mojzer, E.B., M.K. Hrncic, M. Skerget, Z. Knez, \& U. Bren. 2016. Polyphenols: extraction methods, antioxidative action, bioavailability and anticarcinogenic effects. Molecules. 21:901. https://doi.org/10.3390/molecules21070901

Murugesan, G.R., B. Syed, S. Haldar, \& C. Pender. 2015. Phytogenic feed additives as an alternative to antibiotic growth promoters in broiler chickens. Front. Vet. Sci. 2:1-6. https://doi.org/10.3389/fvets.2015.00037

Nirogi, R., V. K. Goyal, S. Jana, S.K. Pandey, \& A. Gothi. 2014. What suits best for organ weight analysis: review of relationship between organ weight and body/brain weight for rodent toxicity studies. Int. J. Pharm. Sci. Res. 5: 1525-1532.

Pandey, A., \& M. Shweta. 2011. Antifungal properties of Psidium guajava leaves and fruits against various pathogens. Pharmaceut. Biomed. Sci. J. 13: 6 pp.

Parashuramulu, S., D. Nagalakshmi, S.D. Rao, K.M. Kumar, \& P.S. Swain. 2015. Effect of zinc supplementation on anti oxidant status and immune response in buffalo calves. Anim. Nutr. Feed Techn. 15:179-188. https://doi. org/10.5958/0974-181X.2015.00020.7

Perry, J.J.P., D.S. Shin, E.D. Getzoff, \& J.A.Tainer. 2010. The structural biochemistry of the superoxide dismutases. Biochim. Biophys. Acta. 1804:245-262. https://doi. org/10.1016/j.bbapap.2009.11.004

Rajendran, R., C. Balakumar, A. Hasabo, M. Ahammed, S. Jayakumar, K. Vaideki, \& E.M. Rajesh. 2010. Use of zinc oxide nano particles for production of antimicrobial textiles. Int. J. Eng. Sci. Technol. 2:202-208. https://doi. org/10.4314/ijest.v2i1.59113

Rivai, H., L. Putriani, \& Mahyuddin. 2010. Karakterisasi flavonoid antioksidan dari daun jambu biji (Psidium guajava L.). J. Farm. Higea. 2: 127-136.

Rostagno, H.S., L.F.T. Albino, M.I. Hannas, J.L. Donzele, N.K. Sakomuro, F.G. Perazzo, A. Saraiva, M.L.T. Abreu, P.B. Rodrigues, R.F. Oliveira, S.L.T. Barreto, \& C.O. Brito. 2017. Brazilian tables for poultry and swine. Federal University of Viçosa-Department of Animal Science.

Saleh, A.A., B. Gálik, H. Arpášová, M. Capcarová, A. Kalafová, M. Šimko, M. Juráček, M.B. Rolinec, D. Bíro, \& A.M.A. Abudabos. 2017. Synergistic effect of feeding Aspergillus awamori and lactic acid bacteria on performance, egg traits, egg yolk cholesterol and fatty acid profile in laying hens. Italian. J. Animl. Sci. 16: 132-139. https://doi.org/10.1080/18 28051X.2016.1269300

Saleh, A.A., M.M. Ragab, E.A.M. Ahmed, A.M. Abudabos, \& 
T.A. Ebeid. 2018. Effect of dietary zinc-methionine supplementation on growth performance, nutrient utilization, antioxidative properties and immune response in broiler chickens under high ambient temperature. J. Appl. Anim. Res. 46:820-827. https://doi.org/10.1080/09712119.2017.140 7768

Salim, H.M., H.R. Lee, C. Jo, S.K. Lee, \& B.D. Lee. 2011. Supplementation of graded levels of organic zinc in the diets of female broilers: effects on performance and carcass quality. Br. Poult. Sci. 52:606-612. https://doi.org/10.1080/0 0071668.2011.616485

Seil, J.T., \& T. J. Webster. 2012. Antimicrobial applications of nanotechnology: methods and literature. Int. J. Nanomedicine. 7: 2767-2781. https://doi.org/10.2147/IJN. S24805

Setyawati, M.I., C.Y. Tay, \& D.T. Leong. 2015. Nanotoxicity: mechanistic investigation of the biological effects of $\mathrm{SiO} 2$, $\mathrm{TiO} 2$, and $\mathrm{ZnO}$ nanoparticles on intestinal cells. Small. 11: 3458-3468. https://doi.org/10.1002/smll.201403232

Sharma, V., P. Singh, A.K. Pandey, \& A. Dhawan. 2012. Induction of oxidative stress, DNA damage and apoptosis in mouse liver after sub-acute oral exposure to zinc oxide nanoparticles. Mutat. Res. Genet. Toxicol. Environ. Mutagen. 745: 84-91. https://doi.org/10.1016/j. mrgentox.2011.12.009

Siddiqi, K.S., A. Rahman, Tajuddin, A. Husen. 2018. Properties of Zinc Oxide Nanoparticles and Their Activity Against Microbes. Nanoscale. Ress. Lett. 13: 141. https://doi. org/10.1186/s11671-018-2532-3

Sinurat, A.P., E. Wina, S.I.W. Rakhmani, T. Wardhani, T. Haryati, \& T. Purwadaria. 2018. Bioactive substances of some herbals and their effectiveness as antioxidant, antibacteria and antifungi. JITV. 23: 18-27. https://doi. org/10.14334/jitv.v23i1.1660

Slavin Y.N., J. Asnis , U. O. Häfeli, \& H. Bach. 2017. Metal nanoparticles: understanding the mechanisms behind antibacterial activity. J. Nanobiotechnol. 15:65. https://doi. org/10.1186/s12951-017-0308-z

Souza R.C., U. Leticia, Haberbeck, G. Humberto, Riella, H.B. Deise, Ribeiro, \& B. A. M. Carciof. 2019. Antibacterial activity of zinc oxide nanoparticles synthesized by solochemical process. Brazil J. Chem. Eng. 36:885 - 893. https:// doi.org/10.1590/0104-6632.20190362s20180027

Stanacev, V., D. Glamocic, N. Milosevic, N. Puvaca, V. Stanacev, \& N. Plavsa. 2011. Effect of garlic (Allium sativum L.) in fattening chicks nutrition. Afr. J. Agric. Res. 6: 943-948.

Starcevic, K., L. Krstulovic, D. Brozic, M. Mauric, Z. Stojevic, Z. Mikulec, M. Bajic, \& T. Mašek. 2015. Production performance, meat composition and oxidative susceptibility in broiler chicken fed with different phenolic compounds. J. Sci. Food. Agric. 95:1172-1178. https://doi. org/10.1002/jsfa.6805

Swain, P.S., S.B.N. Rao, D. Rajendran, G. Dominic, S. Selvaraju. 2012. Nano zinc, an alternative to conventional zinc as animal feed supplement: A review. Anim. Nutr. 2: 134-141. https://doi.org/10.1016/j.aninu.2016.06.003

Syafwani, S., R.P. Kwakkel, \& M.W.A. Verstegen. 2011. Heat stress and feeding strategies in meattype chickens. World's Poult. Sci. J. 67 : 653-674. https://doi.org/10.1017/ S0043933911000742

Vinus \& N. Sheoran. 2017. Role of nanotechnology in poultry nutrition. Int. J. Pure. App. Biosci. 5: 1237-1245. https://doi. org/10.18782/2320-7051.5948

Wahab, R., F. Khan, Y.K. Mishra, J. Musarrat, \& A.A. AlKhedhairy. 2016. Antibacterial studies and statistical design set data of quasi zinc oxide nanostructures. Rsc. Advances. 38:32328-32339. https://doi.org/10.1039/ C6RA05297E

Xie Y., Y. He, P. L. Irwin, T. Jin, \& X. Shi. 2011. Antibacterial activity and mechanism of action of zinc oxide nanoparticles against Campylobacter jejuni. Appl. Environ. Microb. 77:2325-2331. https://doi.org/10.1128/AEM.02149-10

Yan, G., Y. Huang, Q. Bu, L. Lv, P. Deng, \& J. Zhou. 2012. Zinc oxide nanoparticles cause nephrotoxicity and kidney metabolism alterations in rats. J. Environ. Sci. Health. 47:577588. https://doi.org/10.1080/10934529.2012.650576

Yuan, J., Z. Xu, C. Huang, S. Zhou, \& Y. Guo. 2011. Effect of dietary Mintrex-Zn/Mn on performance, gene expression of $\mathrm{Zn}$ transfer proteins, activities of $\mathrm{Zn} / \mathrm{Mn}$ related enzymes and fecal mineral excretion in broiler chickens. Anim. Feed. Sci. Technol. 168:72-79. https://doi.org/10.1016/j. anifeedsci.2011.03.011

Zhang, F., Y. Li, M. Yang, W. Li. 2012. Content of heavy metals in animal feeds and manures from farms of different scales in northeast china. Int. J. Environ. Res. Piublic. Health 9:2658-2668. https://doi.org/10.3390/ijerph9082658

Zhao, C.Y., S.X. Tan, X.Y. Xiao, X.S. Qiu, J.Q. Pan, \& Z.X. Tang. 2014. Effects of dietary zinc oxide nanoparticles on growth performance and antioxidative status in broilers. Biol. Trace. Elem. Res. 160:361-367. https://doi.org/10.1007/ s12011-014-0052-2

Zhou, T.X., Z.F. Zhang, \& I.H. Kim. 2013. Effects of dietary Coptis chinensis herb extract on growth performance, nutrient digestibility, blood characteristics and meat quality in growing-finishing pigs. Asian-Australas. J. Anim. Sci. 26:108-115. https://doi.org/10.5713/ajas.2011.11400 